\title{
Gene Allen, Making National News. A History of Canadian Press (Toronto: University of Toronto Press, 2013). 443 pp. \$36.95 Paperback.
}

For historians, newspapers have long played an important supporting role in their studies. They cover day-to-day events, and can give researchers an idea of the pulse of their readers. Too few are those who have done historical studies of the institution of media and its business. Gene Allen quite favourably fills this void with his history of the Canadian Press.

The readers should beware, however, as this book is not a history of print media in Canada as the name could suggest, but rather of the non-profit cooperative Canadian Press, or CP, as it is commonly known in journalistic circles. Founded in 1917, CP developed into a quasi-monopolistic news producing behemoth at the service of its members. It contributed, through "banal nationalism" and the sheer volume of its readership to the development of Canadian identity. Based on the CP papers, various interviews with former journalists as well as with numerous clippings of its member newspapers, Allen has produced an agreeable piece of research which, one would hope, will persuade others to follow in his footsteps in order to better understand print and broadcast media in Canada.

Although this study deals with the creation of a national network of news, the material and technological conditions within which the CP evolved are quite present in the unfolding of his narrative. Indeed, for much of the studied period (1917-1970), the CP is wholly dependent on leased telegraphic lines, which, at great cost, permitted it to send news stories back and forth to its members throughout the country. Further explored is the rather ham-fisted way in which the organisation dealt with a union drive by the American Newspaper Guild, as well as it's almost dogmatic underpaying of its staffers.

In fact, $\mathrm{CP}$ is shown to constantly struggle with its noble desire to bring about a Canadian spin on news and its (albeit self-imposed) cost limitations, often resorting to draconian cost-cutting measures to keep a thin bottom line. The ability to pay (or the willingness to) often trumps the ambition of this organisation. Indeed, composed mainly of competing newspapers (Toronto being a remarkably heated newsprint market), CP is often at odds with its own interests. For example, admitting new members in an established market brings about an important hurdle to the newcomer in the form of prohibitive entry fees. At times, CP appears as a complex, multi-layered game of chess in which some players cannot even control their pawns.

The narrative can appear at times to be cumbersome. The author often privileged details of the CP over analysis of news services in the development of print and broadcast media. It is abundantly clear to this reviewer that Allen is more than capable of astute and intelligible analysis. His introduction demonstrates that we are in capable theoretical hands, and his last chapter demonstrates 
his willingness to dirty these same hands with empirical data. For whatever reason, it was judged more agreeable to have a narrative that is more inclined towards the institutional history of $\mathrm{CP}$ with subtle analysis here and there. Indeed, the author often attempts to do too much, which is the principle trap one falls into when working on a long-time fallow field. This translates into unnecessary detail and a series of lengthy paragraphs that can at times feel rather oppressive and may lead certain readers gasping for air.

The temptation to delve into the nuts and bolts of certain developments at CP (photo services is but a banal example) does distract to the principle issue at hand. This can lead to some problems with the coherence of the text. One particular section which leads in with a bite-sized paragraph on the creation of the French-language services ends up discussing at length another issues altogether, leaving the reader perplexed as to the structure of the text.

Further, the treatment of French Canada something this reviewer commends, as many historians would rather not bother with, leaves to be desired. Does CP have the same impact with its "banal nationalism" in French Canada? The author states, for example, that:

Important as the $\mathrm{CBC}$ has been as a cultural entity in Canada, one could argue that $\mathrm{CP}$ was more influential: $\mathrm{CBC}$ never accounted for more than a fraction of all radio stations, whereas virtually every daily newspaper (and most broadcast stations) in Canada relied on CP's service. It was the chief vehicle of "mediated publicness" in Canada for most of the twentieth century, providing a common base of information across the country (and a shared correction à la [Benedict] Anderson to all the others who were following the same stories) (16).

With the struggles of CP in French Canada and the importance of Agence FrancePresse in that market, one wonders if this statement would benefit from nuance in relation to the French-language newspapers and, indeed, in relation to RadioCanada.

Further questions have come to the reviewers mind relating to French Canada. What leadership role did the French newspapers take in the organisation, if any? The author clearly demonstrates the dissatisfaction of French-language newspapers with $\mathrm{CP}$ as well as the important efforts the organisation undertakes to compensate for this. However, one gets the impression that the French-language members simply grumbled when they paid their yearly dues. Finally, his final chapter on the use of CP material in the Halifax Chronicle-Herald could have profited from a comparative analysis with a French-language newspaper like Le Droit.

Allen, having accumulated a remarkable twenty years worth of experience in the journalistic field shows to be quite beneficial to readers who look up to him to expose a complete and rigorous study of CP's history. The author 